\title{
Remarks on Myeloid Sarcoma in Children
}

\author{
Çocuklarda Myeloid Sarkom Üzerine Yorumlar
}

Sevgi Gözdaşoğlu

Retired Professor of Pediatrics, Hematology and Oncology

\section{To the Editor,}

Arslantaş et al. [1] reported "A Rare Cause of Paraplegia: Myeloid Sarcoma" in a recent issue of this journal. I would like to remark on a few points not mentioned in that paper.

Extramedullary infiltrations (Els) of the soft tissue, also known as myelosarcoma (MS) or granulocytic sarcoma (GS), occur in approximately $4 \%$ to $5 \%$ of children with acute myeloid leukemia (AML) in western countries [2]. MS may develop before, during, or after the occurrence of AML. AML is a clinically and genetically heterogeneous disease. Immunohistochemistry and immunophenotyping are important for the accurate diagnosis of AML. White blood cell (WBC) count at diagnosis, FAB subtypes, and cytogenetics are the main important prognostic factors. For that reason, these analyses should be performed for all patients $[3,4,5]$.

Cytogenetic analysis has become an important parameter for the diagnosis, prognosis, and treatment selection of AML. t( $8 ; 21)$ is the most common abnormality and it is primarily found in the M2 subtype. The inv(16) and $t(16 ; 16)$ associated with M4Eo and $t(15 ; 17)$ and $t(11 ; 17)$ associated with the M3 subtype are favorable, whereas $11 \mathrm{q} 23$ associated with M4 and M5 variants is found unfavorable for prognosis [2]. Xu et al. [5] reported that monosomal karyotypes are independent risk factors for poor prognosis.

The prognostic significance of MS in childhood AML is still controversial. Some groups reported an unfavorable prognosis but others demonstrated a favorable outcome $[3,4,6]$. Central nervous system leukemia and MS together with high initial WBC count at diagnosis are high risk factors for relapse [6].

Orbital granulocytic sarcoma (OGS) was first reported in 1971 by Çavdar et al. [7] from Turkey. Some researchers in Turkey also reported that there was a connection between AML and EI in several retrospective analyses of patients as well as in some case reports $[8,9,10]$. Çavdar et al. [7] analyzed 33 patients presenting with OGS characterized by exophthalmos, proptosis, chemosis, and orbital masses (Figure 1). OGS was noted in 33 (27\%) of 121 patients. These patients were compared with 41 cases of AML without OGS seen during the same period. The

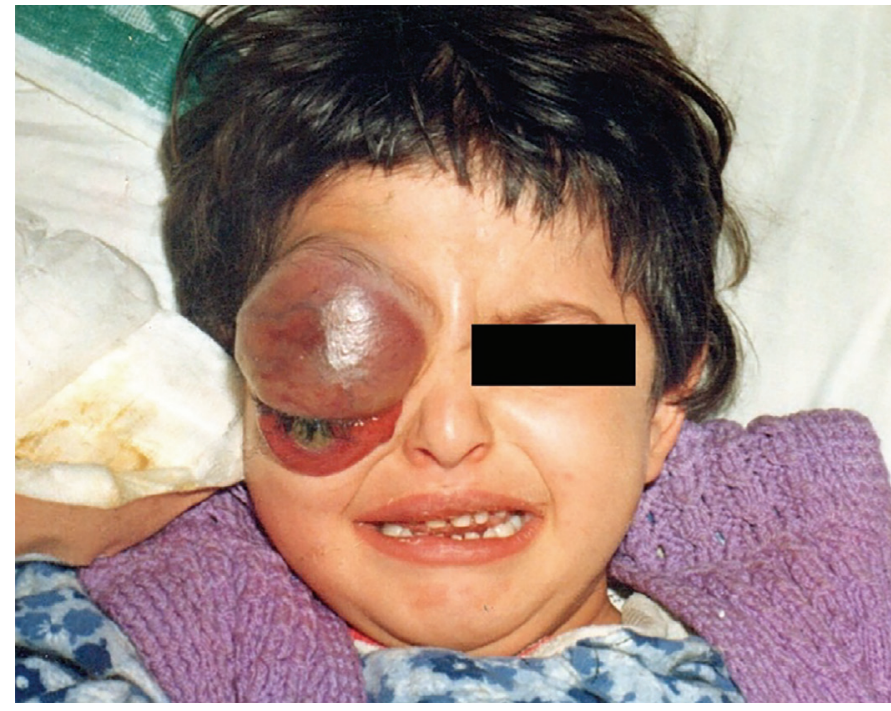

Figure 1. Appearance of exophthalmos, proptosis, chemosis, and orbital mass.

majority of the patients with OGS were of low socioeconomic status. The mean age was 6.7 years and 24 of the patients were male while 9 were female. OGS occurs in patients with M4 or M5 subtypes. Hematological findings in the two groups were not significantly different. Cytogenetic study revealed that the $t(8 ; 21)$ abnormality was frequent. The expression of tissue adhesion molecules CD56 and CD44 and the expression of MDR $(p-g p)$ were more common in OGS cases. These findings might explain the different prognosis in patients with OGS $[4,11]$. The mean survival time of 8.7 months in the OGS group was significantly shorter than that of patients without OGS (28.6 months) $(p<0.01)$ treated before 1990 [4]. Çavdar et al. [11] suggested that this type of presentation could indicate a special high-risk biological entity. Further molecular and therapeutic studies are required for a better understanding of the reasons for tissue involvement and to choose the most effective treatment options.

Keywords: Myeloid sarcoma, Cytogenetic, Prognosis

Anahtar Sözcükler: Myeloid sarkom, Sitogenetik, Prognoz

Informed Consent: Informed consent was received from the parents. 
Conflict of Interest: The author of this paper has no conflict of interest, including specific financial interests, relationships, and/or affiliations relevant to the subject matter or materials included.

\section{References}

1. Arslantaş E, Bayram C, Odaman Al I, Uysalol E, İribaş A, Akı H, Adaletli i, Ayçicek A, Özdemir N. A rare cause of paraplegia: myeloid sarcoma. Turk J Hematol 2018;35:206-207.

2. Bennett C, Hsu K, Look AT. Myeloid leukemia, myelodysplasia and myeloproliferative disease in children. In: Nathan DG, Orkin SH, Ginsburg D, Look AT (eds). Nathan and Oski's Hematology of Infancy and childhood. Philadelphia, WB Saunders Company, 2003.

3. Bisschop MM, Révész $T$, Bierings $M$, van Weerden JF, van Wering ER, Hählen $K_{\text {, van }}$ der Does-van den Berg A. Extramedullary infiltrates at diagnosis have no prognostic significance in children with acute myeloid leukemia. Leukemia 2001;15:46-49.

4. Gözdaşoğlu S, Yavuz G, Ünal E, Taçyıldız N, Çavdar AO. Orbital granulocytic sarcoma and AML with poor prognosis in Turkish children. Leukemia 2002;16:962.

5. Xu J, Huang B, Liu X, Zhang Y, Liu Y, Chen L, Luan Y, Li N, Chu X. Poor prognosis in acute myeloid leukemia patients with monosomal karyotypes. Turk J Hematol 2017;34:126-130.
6. Kobayashi R, Tawa A, Hanada R, Horibe K, Tsuchida M, Tsukimoto I; Japanese childhood AML cooperative study group. Extramedullary infiltration at diagnosis and prognosis in children with acute myelogenous leukemia. Pediatr Blood Cancer 2007;48:383-398.

7. Çavdar A0, Gözdaşoğlu S, Arcasoy A, Demirağ B. Chloroma like ocular manifestations in Turkish children with acute myelomonocytic leukemia. Lancet 1971;1:680-682.

8. Baytan B, Evim MS, Güneş AM, Kocaeli H, Balaban Ş, Korfalı E, Tüzüner N. Cerebellar granulocytic sarcoma: a case report. Turk J Hematol 2012;29:177180.

9. Kaygusuz Ç, Kankaya D, Ekin C, Topçuoğlu P, Kuzu I. Myeloid sarcomas: a clinico-pathologic study of 20 cases. Turk J Hematol 2015:32:35-42.

10. Hiçsönmez G, Çetin M, Tuncer AM, Yenicesu I, Aslan D, Özyürek E, Ünal S. Children with acute myeloblastic leukemia presenting with extramedullary infiltration: the effects of high-dose steroid treatment. Leuk Res 2004;28:25-34.

11. Çavdar AO, Babacan E, Gözdaşoğlu S, Kılıçturgay K, Arcasoy A, Cin S, Ertem $\mathrm{U}$, Erten J. High risk subgroup of acute myelomonocytic leukemia (AMML) with orbito-ocular granulocytic sarcoma (OOGS) in Turkish children. Retrospective analysis of clinical, hematological, ultrastructural and therapeutical findings of thirty-three OOGS. Acta Haematol 1989;81:8085.

๑Copyright 2019 by Turkish Society of Hematology

Turkish Journal of Hematology, Published by Galenos Publishing House

\section{Reply from the Authors}

\section{To the Editor,}

We read the letter regarding our publication, "A Rare Cause of Paraplegia: Myeloid Sarcoma".

Because of its different localization and symptoms, myeloid sarcoma is difficult to diagnose, in particular in patients without initial bone marrow involvement. Thus, the correct diagnosis of MS is often delayed and the misdiagnosis rate is high. Our patient was referred to us with a complaint of hemiparesis and a subsequent thoracolumbar mass detected by magnetic resonance imaging, and no blasts were detected on peripheral blood film but bone marrow aspiration showed blasts compatible with AML. In this regard, the aim of our publication was to highlight to diagnostic challenges and rare presentations of MS in childhood.

We believe, like the author of the preceding letter, that immunohistochemistry, immunophenotyping, and cytogenetic and molecular examinations play an important role in the diagnosis and prognosis, and before creating a treatment plan these should be performed for all patients. Radiology, histology, immunophenotyping, and molecular analyses are all essential for risk stratification and treatment planning. The next step is giving AML-based systemic chemotherapy and, in some cases, as in our case, surgery and/or radiotherapy may be indicated.

We could not mention the clinical, cytogenetic, and molecular features of MS extensively, as our publication was in the format of a Letter to the Editor. We would like to thank the author for her valuable contribution.

Best Regards, Esra Arslantaş, Cengiz Bayram, Işık Odaman Al, Ezgi Uysalol, Ayça İribaş, Hilal Akı, İbrahim Adaletli, Ali Ayçiçek, Nihal Özdemir 